\title{
THE SCORPIONS OF THE WESTERN PART OF THE UNITED STATES, WITH NOTES ON THOSE OCCURRING IN NORTHERN MEXICO
}

\author{
By H. E. Ewing,
}

Of the Bureau of Entomology, United States Department of Agriculture

\section{INTRODUCTION}

During recent years many inquiries have been received in regard to the identity, habits, and the seriousness of the stings of our scorpions. Most of these have come from the Southwestern States where scorpions are abundant and where the activities of the people bring many of them in frequent contact with these venomous arachnids. Scorpions in this section of the country are a great annoyance. Although serious cases of stinging have been few there, across the border in northern Mexico many reports of serious consequences following scorpion stings have been made. In the State of Durango even death has been attributed to them. Because of these inquiries and reports it was decided to investigate especially the scorpions of the Southwest. This paper is the first to be prepared dealing with them. In it a taxonimic synopsis is given of all the species reported from the United States west of the Mississippi River. In dealing with the more common species the distribution, as far as known up to the present, has been given. Although but little has been learned of the life histories, habits, and effects of the venom of most of our species, that which is known is summarized. More complete revisionary papers dealing with the taxonomy and literature of the species occurring in North America are planned.

Notes are frequently added concerning species occurring in northern Mexico. These are of particular value since the writer has had the opportunity of studying a large collection of scorpions taken in Durango, Mexico and some other localities in that country by Dr. W. J. Baerg, of the University of Arkansas. Also it is of much importance to know if the species which are being reported as being fatal to man in Durango occur within our borders and if so to what extent and under what conditions. 
Before attempting the present synopsis the writer was sent by the Bureau of Entomology to the States of Louisiana, Texas, and Arizona to investigate scorpion conditions and make collections. While there something was learned of the habits of scorpions and of man's encounters with them; also many live specimens were captured. Various persons in the Southwest aided the writer in securing information and in collecting specimens. Special mention should be made of the following: Mr. E. V. Walter, Bureau of Entomology, San Antonio, Tex.; Mr. H. B. Parks, apiculturist, State Apicultural Research Laboratory, near San Antonio, Tex.; Mr. V. L. Wildermuth, Bureau of Entomology, Tempe, Ariz.; Mr. E. E. Russell, Bureau of Entomology, Yuma, Ariz., and several members of the Bureau of Entomology staff at Dallas, Tex.

\section{CONCERNING SCORPIONS IN GENERAL}

Scorpions are large, more or less crablike, arachnids of very ancient origin. By leading authorities they are considered as the most ancient and generalized of the true arachnids. They have the body divided into two definite regions, the cephalothorax and the abdomen. The latter, however, has the posterior part greatly narrowed and formed into a so-called "tail." This region, known as the postabdomen, bears on its distal segment the sting, the only weapon which the scorpion has to make itself dreaded by man.

The legs of a scorpion are eight in number throughout life. They are clawed at the end and are all similar. The palpi are greatly enlarged, and the last two segments form a powerful pinching structure known as the chelae. The true jaws, which should be known as the chelicerae, are much smaller structures than the chelae and are partly concealed from above by the front edge of the carapace, the hard covering of the cephalothorax.

The organs of special senses are poorly represented; however, the eyes are conspicuous and of two kinds. There is a pair of large eyes situated on the sides of a turret or tubercle near the middle of the dorsal surface of the cephalothorax and several smaller eyes, or ocelli, situated on the lateral margins. The more important structures used in taxonomy are given in the accompanying illustration.

Scorpions are found in greatest abundance in tropical and subtropical countries. Only a few species range far into the temperate zones and none extend across either of these zones. The taxonomic work on the United States species has been done chiefly by Wood, Marx, and Banks. In the past 20 years no extended paper has appeared dealing with our species. The subject of the control of scorpions and of the treatment of their stings will be dealt with in a subsequent paper. 
But four families of scorpions occur in the United States and northern Mexico. These may be separated as follows:

KEY TO THE FAMILIES OF SCORPIONS OCCURRING IN WESTERN UNITED STATES AND NORTHERN MEXICO

$A^{1}$. Sternum subpentagonal, with sides almost parallel.

$B^{1}$. Membrane at base of last tarsal segment of most of the legs with a single spur; postabdomen frequently reduced Scorpionidae.

$B^{2}$. Membrane at base of last tarsal segment of most of the legs with two spurs.

$C^{1}$. Only two ocelli on each lateral margin of carapace Chactidae. (Only one genus, Broteas, in United States and Mexico.)

$\mathrm{C}^{2}$. With 3 to 5 ocelli on each lateral margin of carapace_-_-_Vaejovidae. $\mathbf{A}^{3}$. Sternum triangular, the sides being strongly convergent anteriorly; membrane at the base of last tarsal segment of most of the legs with two unbranched spurs; fixed arm of chelicerae without ventral tooth.

Buthidae.

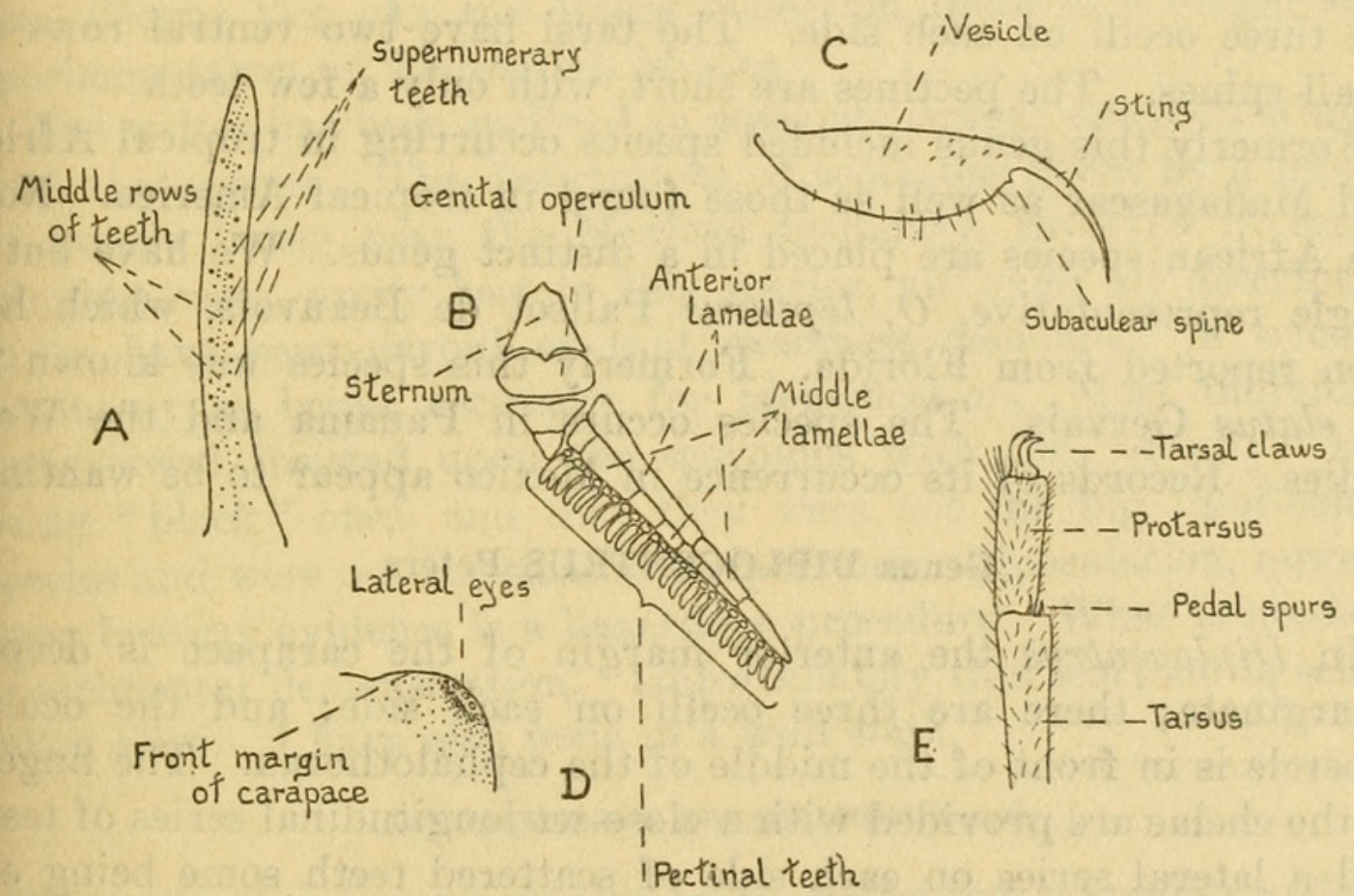

Fig. 1.-Detail dratwings of parts of Centruroides vittatus Say to illustrath STRUCTURES OF TAXONOMIC IMPORTANCE: A, FINGER OF CHELICERA; B, LEFT HALF OF STERNAL REgion OF MALE; C, CAUDAL SEgMENT OF MALE; D, aNTERo-lateral Section OF CARAPACE; E, LAST TWO SEGMENTS OF LEG IV

\section{Family SCORPIONIDAE}

In this family the sternum is subpentagonal in shape, the sides being almost parallel. The membrane at the base of the last tarsal segment of most of the legs bears a simple spur. The postabdomen is usually somewhat, or even decidedly, reduced.

The family is well represented in Central America and the tropical regions of the Old World but is poorly represented in the central part of South America and in the United States. Dr. de Mello Campos (1924) mentions only a single species as occurring in Brazil, and but 
three species are known from the United States. Our two subfamilies and two genera may be separated as follows:

KEY TO THE SUBFAMILIES AND GENERA OF THE FAMILY SCORPIONIDAE OCCURRING IN THR UNITED STATES

$\mathbf{A}^{\mathbf{1}}$. No spine or tubercle under the sting on caudal vesicle.

Only a single genus represented in the United States.

Subfamily Ischnurinae.

Opisthacanthus Peters.

A'. A spine or tubercle under the sting near its base_-_Subfamily Diplocentrinae. Only a single genus represented in the United States.

Diplocentrus Peters.

\section{Genus OPISTHACANTHUS Peters}

In Opisthacanthus the pedipalps are very large, and the postabdomen is reduced and compressed. The carapace is deeply emarginate in front and has a median groove for the entire length. There are three ocelli on each side. The tarsi have two ventral rows of small spines. The pectines are short, with only a few teeth.

Formerly this genus included species occurring in tropical Africa and Madagascar as well as those found in tropical America. Now the African species are placed in a distinct genus. We have but a single representative, $O$. lepturus Palisot de Beauvois, which has been reported from Florida. Formerly this species was known as O. elatus Gervais. The species occurs in Panama and the West Indies. Records of its occurrence in Mexico appear to be wanting.

\section{Genus DIPLOCENTRUS Peters}

In Diplocentrus the anterior margin of the carapace is deeply emarginate; there are three ocelli on each side; and the ocular tubercle is in front of the middle of the cephalothorax. The fingers of the chelae are provided with a close-set longitudinal series of teeth and a lateral series on each side of scattered teeth some being enlarged. The fifth segment of the postabdomen has a ventral semicircular area bounded by a row of granules. The sting is provided with a basal tubercular tooth.

The genus is found throughout most of tropical America. Dr. de Mello Campos (1924) records a single species from Brazil. Three species occur in the United States, two in the Southwest and one in Florida. The southwestern species may be separated as follows:

KEY TO THE WESTERN UNITED STATES SPECIES OF DIPLOCENTRUS

Color very dark reddish brown, almost black; length from 5 to $7 \mathrm{~cm}$.; pectinal teeth 14

D. whitei (Gervais).

Color reddish brown but not approaching black; length from 4 to $5.5 \mathrm{~cm}$; pectinal teeth 9-11 
D. whitei is a very dark reddish brown scorpion, from 5 to $7 \mathrm{~cm}$. in length, with large stout chelae and short fingers. The sting is scarcely half as long as the vesicle that bears it and is strongly curved. The subaculear tooth is large and shaped like a tubercle. The caudal vesicle bears several long setae distally.

Although the type specimen of this species came from Mexico, according to Pocock (1902) : "No exact locality in Mexico has ever been assigned to specimens of this species." Pocock further states that the "example in the British Museum is the type of the species, which is dried and too imperfect to be available for description." In the United States National Museum there are only two specimens. They were taken on the Mohave Desert, Calif. The description and figures given by Pocock (1902) were from an adult male and female taken at San Diego, Tex. In the Baerg collection there is a single adult specimen taken at Tlahualilo, Mexico.

The writer has been inclined to associate serious scorpion stinging with this species. The descriptions of scorpions given by a number of people living near the Mexican boundary, involved in serious stinging cases, apply best to this species, although all descriptions given have been devoid of that exactness demanded in scientific taxonomy as being necessary for identification. Most individuals interviewed insisted upon the scorpions with the "deadly" sting being "black" ones, and that they were not the big light-colored species and were not the smaller striped ones. Speculation, however, upon hearsay evidence is a hazardous procedure. What is needed is experimental demonstration. Unfortunately this scorpion is seldom taken alive. I have seen none in a wild state.

\section{DIPLOCENTRUS KEYSERLINGI Karsch}

This scorpion is very similar to $D$. white $i$ but is smaller and of a lighter color and has not more than 11 teeth in the pectinal comb, while $D$. whitei has 14. Also the carapace is more granulate than in D. whitei.

Comparatively little is known concerning the distribution of this species. Pocock gave but two records for it, both from Mexico. Banks (1910) reports it from California, stating that there are specimens in the Marx collection labeled "California." The specimens referred to, which are said to be "nearly black" are probably those marked "Diplocentrus venustus." These large very dark specimens have from 10 to 12 teeth in the pectines, and may prove to be either a new species or a variant of $D$. whitei. Specimens in the National Museum from Paisano, Tex., determined as D. whitei should be considered as $D$. keysertingi. In the Baerg collection there are 
two large specimens from Durango, Mexico, and six smaller ones (including some that are evidently immature) from Atotonilco, Mexico.

It would be of much importance to experiment with this species to see if it could be implicated in any way in the serious cases of scorpion stinging reported from Durango, Mexico.

\section{Family CHACTIDAE}

The family Chactidae differs from our other American scorpion families in having only two ocelli on each side of the carapace. The sternum has straight, but slightly converging sides and an outwardly angulate anterior margin. It is as long as, or longer than broad.

The family has a wide distribution in the world but is wanting in the Ethiopian and Australian regions. Kraepelin (1905) lists four genera and 29 species for the Neotropical Region, all of which are characteristic of this region. In the United States but a single genus and species is found.

\section{Genus BROTEAS Koch}

In the genus Broteas the latest tarsal segment bears two rows of short spines on the under surface. Segments I-IV of the postabdomen are keeled below and the stigmata are slitlike. Only one species occurs in the United States.

\section{BROTEAS ALLENI (Wood)}

\section{ALLEN'S SCORPION}

This is a small dark-brown species. The hands are slightly keeled and swollen; the fingers are very short, being but little over one-half as long as the hand. The small, slender tail has the vesicular segment depressed; the sting broadens out proximally into the vesicle. A National Museum specimen measures $3 \mathrm{~cm}$. in length.

This species occurs, as far as known, only in the extreme southwestern part of North America. The type was taken at Cape San Lucas, Lower California. There are two specimens in the National Museum collection, both from Fort Tejon, Calif. These two records are the only ones known to the writer, hence it is assumed that the species is rare. Its habits are unknown.

\section{Family VAEJOVIDAE}

Members of the family Vaejovidae have the sternum subpentagonal, the sides being subparallel. There are two spurs on the membrane at the base of the last tarsal segment, and from three to five 
ocelli on each side of the cephalothorax. This family is rather closely related to the family Chactidae, but differs from it in having more than two ocelli on each side of the cephalothorax.

The family is best represented in North and Central America, but also occurs in the northern part of the Old World and in South America. Dr. de Mello Campos (1924) does not mention it in his synopsis of the Brazilian scorpions. The four genera found in the United States may be separated as follows:

KEY TO THE GENERA OF VAEJOVIDAE OCCURRING IN THE UNITED STATES

$\mathrm{A}^{1}$. Middle area of pectines broken up into more than eight small pieces, the most of which are subcircular; first four segments of postabdomen without single ventral keel.

$B^{1}$. Movabie finger of chelicera with a spinelike tooth on the lower surface. Large hairy scorpions. Hadrurus Thorell.

$\mathrm{B}^{2}$. Movable finger of chelicera without ventral tooth_____Vaejovis Koch. $\mathbf{A}^{3}$. Middle area of pectines more or less indistinctly broken up into seven or less pieces.

$\mathrm{B}^{1}$. Divisions of middle area of pectines unequal and few in number; sting sometimes bulbous near base

Anuroctonus Pocock.

$B^{2}$. Most of the divisions of the middle area of pectines subequal and numbering over five; sting normal Uroctonus Thorell.

\section{Genus HADRURUS Thorell}

In Hadrumus the middle area of the pectines is broken up into more than eight small pieces, those toward the distal end being very small and subcircular. The first four segments of the postabdomen, or cauda, are without the single median keel. The movable finger of the chelicera has a spinelike tooth on its lower surface.

This genus includes only a few North American species. One species and a variety occurs in the southwestern part of the United States and another species in Mexico. These may be separated by means of the following key:

\section{KEY TO THE NORTH AMERICAN FORMS OF HADRURUS}

A $^{1}$. Length over $70 \mathrm{~mm}$; body reddish brown; appendages and postabdomen very hairy; number of teeth in pectines 34 to 40 .

$\mathrm{B}^{1}$. Frontal space of carapace finely granular; hand and brachium finely and closely granular; movable finger longer than carapace.

H. hirsutus Wood.

$\mathbf{B}^{2}$. Frontal space of carapace sparsely studded with large round granules; hand and brachium smooth except on crests; movable tinger shorter than carapace.

H. aztecus Pocock.

$\mathrm{A}^{2}$. Length not over $60 \mathrm{~mm}$; body olive gray; appendages and postabdomen less hairy; number of teeth in pectines 25 to 32 .

H. hirsutus var. arizonensis, new variety. 


\section{HADRURUS HIRSUTUS Wood}

GIANT HAIRY SCORPION

This species (pl. 1, fig. 1) is our largest and most distinctive species. The region in front of the ocular tubercle is very white and in live specimens shows up in sharp relief the lateral ocelli giving the scorpion the appearance of having a face. The body as a whole is a dark yellowish or reddish brown. The appendages and the postabdomen are very hairy, hence the name hirsutus. Some of the alcoholic specimens in the National Museum collection measure over $11 \mathrm{~cm}$. in length. Many spec:mens are much smaller, and in desert situations they are scarcely more than half this size. These, however, should be regarded as a distinct variety.

This large arachnid is found in many places in southwestern United States and northwestern Mexico. National Museum specimens are from Nevada, Arizona, and California, in the United States, and Sonora and Lower California, Mexico. Pocock (1902) questionably reports the species from Guatemala and mentions "two smaller examples for which no locality is known," which probably should be referred to the variety to be described farther on in this paper. The writer obtained a live overwintering female specimen of this species at Tucson, Ariz., March 27, 1927, and has kept her in captivity up to the time of writing this paper, July, 1927. Between April 27 and May 19 she ate three large roaches, two being adults of Periplaneta americana. Since that time she has refused to eat. The specimen at once excavated a pit in the earth at the bottom of the breeding cell and occupied it at all times afterward.

\section{HADRURUS HIRSUTUS, var. ARIZONENSIS, new}

In the desert regions about Phoenix and Tempe, Ariz., there occurs a scorpion that should be regarded as only a variety of hirsutus. It is smaller, less hairy, and the color of the appendages and legs is a light yellowish, while the abdomen is almost black.

Length, varying from 4 to $7 \mathrm{~cm}$.

Type locality.-Papago Saguaro National Monument, Ariz.

Type.-Cat. No. 971, U.S.N.M.

Four specimens obtained, all by the writer; three, including the type, from under stones, Papago Saguaro National Monument, Ariz., March 31, 1927, and one (kept alive) from Tempe, Ariz., March 29, 1927.

This live individual was taken from under a stone in a rocky place at Tempe, Ariz. It was a female specimen much distended, apparently with developing eggs. She was placed in a museum jar and carried about all the way to the Pacific coast and back to Washington, D. C. On April $26 \mathrm{I}$ arrived at Washington and placed her 
in a jar with a deep layer of soil at the bottom and a small piece of wood inclined against one side of the jar. The idea in placing the wood in the jar was to give the scorpion a place to conceal itself as it normally does in nature. One edge of the wood, however, was lifted enough to allow easy vision of the specimen when the jar was held to the light.

During the very first day the scorpion started digging in the sandy soil. This was accomplished by sudden backward jerky movements of one or two legs on a side at a time. The first and second or the second and third legs of a side were most frequently used. After a considerable amount of excavation had been made she remained comparatively quiet in the hole under the wood. Although offered several roaches as food, none were eaten. During the latter part of May she came out from under the piece of wood and did not return until she had dug a tunnel similar to those of gophers. Inside of this tunnel she rested contentedly. This specimen, as well as others kept in captivity, at first showed much activity during the night. When the lights were turned on the scorpion would be found scrambling up the sides of the jar, lifting itself as high as possible by the cauda, then falling back again.

\section{HADRURUS AZTECUS Pocock}

\section{MEXICAN HAIRY SCORPION}

Pocock (1902) described as new a species taken at Jalapa, Mexico. In general appearances it is almost exactly like the well known $H$. hirsutus of the Mexican border, but differs from the latter in a number of minor characters. In aztecus the frontal area of the carapace is studded with large round granules instead of being closely and finely granular; the terga are mostly smooth in front and mesially instead of being finely and coarsely granular as in hirsutus. There are several other differences.

The distribution and habits of this species have not been studied. There are no specimens of it in the United States National Museum, and it is not represented in the Baerg Mexican collection.

\section{Genus VAEJOVIS Koch}

Vaejovis is similar to Hadrurus but is easily distinguished from the latter by the absence of the spinelike tooth on the ventral side of the movable finger of the chelicerae.

The species of Vaejovis are smaller than those of Hadrurus and, with but a single exception in the United States, are much less hairy. In this genus is to be found a majority of the North American members of the family Vaejovidae. One of its species far outranges all other scorpions to the northward in America being found up to, or possibly over, the northern boundary of the United States. 
KEY TO THE UNITED STATES SPECIES OF VAEJOVIS ${ }^{1}$

$\mathbf{A}^{1}$. Hands provided with ridges or keels and granular.

$\mathbf{B}^{1}$. Caudal vesicle densely beset with long hairlike setae, some of which equal the sting in length______

$\mathbf{B}^{2}$. Caudal vesicle practically bare.

$\mathbf{C}^{\mathbf{1}}$. Ventral keels distinct on all the segments of postabdomen; sting about as long as the vesicle from which it arises.

$D^{1}$. Second and third segments of postabdomen longer than broad.

$\mathbf{E}^{1}$. Middle dorsal keel hand well developed, as prominent as the others; sting curved throughout and a little longer than the vesicle that bears it_-_.-- $\mathbf{v}$. punctipalpis Wood.

$\mathrm{E}^{2}$. Middle dorsal keel of hand obsolete; sting curved distally and shorter than vesicle___-_ $\mathbf{v}$. yosemitensis, new species.

$D^{2}$. Second and third segments of postabdomen broader than long.

v. minimus Kraepelin.

$C^{2}$. Ventral keels on first two segments of postabdomen vestigial or wanting; sting not over two-thirds as long as the vesicle from which it arises.

$\mathrm{D}^{\mathbf{1}}$. Integument smooth or finely granular. A light yellowish brown or greenish species_________-_._._. boreus Girard.

$\mathrm{D}^{2}$. Integument coarsely granular. A dark reddish brown species. v. mexicanus Koch.

A $^{1}$. Hands without keels and smooth.

$B^{1}$. Segments IV and V of postabdomen stouter than those in front of them; color greenish or yellowish, with broad, indistinct, yellowish, median stripe on dorsum of abdomen and 4 dark longitudinal lines on under side of postabdomen

v. spinigerus Wood.

$B^{2}$. Segments IV and V of postabdomen scarcely as stout as those in front of them.

$\mathrm{C}^{1}$. Hand slender, not swollen on inside, about twice as long as wide. Western species

v. flavus Marx

$\mathrm{C}^{2}$. Hand not slender, markedly swollen on inside, about one and a half times as long as wide.

$D^{1}$. Segments III and IV of postabdomen without ventral submedian keels. Eastern species_____- $\mathbf{v}$. carolinianus Beauvois.

$\mathrm{D}^{2}$. Segments III and IV of postabdomen with ventral submedian keels. Western species_

V. subcristatus Pocock.

\section{VAEJOVIS HIRSUTICAUDA Banks}

Banks (1910) has described a scorpion of this genus with a very hairy tail. It is reddish brown, very granular, with a slender and very strongly keeled postabdomen, the vesicle of which is brushy because of the large number of hairlike setae it bears. The length is about $31 \mathrm{~mm}$. It was taken in San Bernardino County, Calif.

\section{VAEJOVIS PUNCTIPALPUS Wood}

$V$. punctipalpus is a long species, larger specimens being $6 \mathrm{~cm}$. in length, with a well developed postabdomen. The hands are stout and keeled. It is of a uniform reddish brown color.

1 The species described by Borelli as $\nabla$. silvestrii is not included in this key, as its status is somewhat in doubt. 
This species occurs in the southwestern part of the United States and the northwestern part of Mexico. In the National Museum collection there are specimens from Utah, Nevada, California, New Mexico, and Lower California. Essig (1926) reports it also from Arizona.

\section{VAEJOVIS YOSEMITENSIS, new species}

\section{YOSEMITE SCORPION}

As far as known only a single species of scorpion occurs in the Yosemite Valley. This species (pl. 2, fig. 3) was taken during the spring of 1927 under the rocks at the base of the Yosemite Falls. Here, and only here, in a perpetual fog of spray from the falling waters of one of the world's highest cataracts, could specimens be obtained. Just why such a situation was so well suited to the species is hard to understand. Usually scorpions prefer much hotter and drier places. The technical description follows:

General color reddish brown, with the finger of the pedipalps and the abdomen proper darker than the rest. Hands stout and well keeled, the inner dorsal keel continues almost to the tip of the fixed finger, the outer dorsal keel ends with the hand, middle keel reduced, obsolete, but darkened with pigment. Fingers strongly upcurved and equal to the hand in length. Carapace with broad deep anterior marginal notch, deep median groove and granular surface. Abdomen uniformly colored above. Pectinal comb reaching to the sides of the abdomen, with 14 teeth and 10 to 12 pieces in middle area. Postabdomen longer than abdomen proper, ventral keels strongly tubercular and on all segments except the caudal vesicle. Sting much less in length than the vesicle, almost straight at the base and very broad. It is black at the tip but of the same color as the vesicle at the base.

Total length, $40 \mathrm{~mm}$; length of postabdomen, $23.5 \mathrm{~mm}$; greatest width of carapace, $7.4 \mathrm{~mm}$. (measurements made from fresh alcoholics).

Type locality.-Yosemite Valley, Calif.

Type.-Cat No. 972, U.S.N.M.

Description based on three specimens taken during April, 1927, by Dr. Fred Ewing and the writer on the ground under rocks at the base of Yosemite Falls. One of these was a young specimen. It was taken on April 14th. The other two were adults and were taken on the 15 th.

\section{VAEJOVIS MINIMUS Kraepelin}

Kraepelin (1911) described a small species of Vaejovis from San Pedro, Calif. In this species the upper side of the body is reddish brown and the under side, as well as the legs, is yellowish. The postabdomen is very short, each of the first three segments being broader 
than long. There are 10 teeth in the pectinal comb in the male and 9 in that of the female. Nothing is known of the habits or distribution of the species.

\section{VAEJOVIS BOREUS (Girard)}

\section{NORTHERN SCORPION}

This scorpion (pl. 1, fig. 2), the most northern in its distribution of any American species, is unmarked and dark yellowish brown. In length it varies from 3.5 to $5 \mathrm{~cm}$., and is of slender proportions. The sting has a broad base which expands imperceptibly into the vesicle.

Webster (1923) reported the species as occurring in North Dakota in the region known as the "Bad Lands." His specimens were identified by the writer. Chamberlin (1924) identified a specimen of this species taken at Medicine Hat, Alberta, Canada. It is not known for sure, however, that $V$. boreus is actually established in Alberta. Scorpions are constantly found under artificial conditions far north of their natural range, where they have been transported by shipments of household goods, fruit, lumber, or other materials. Such specimens have been determined by the writer from Washington and Philadelphia. It is well known, however, that in a state of nature scorpions are not found in the environs of either of these two cities. In the National Museum there are specimens from the following States: Arizona, Nebraska, Oregon, Idaho, Wyoming, Montana, South Dakota, and North Dakota. It is believed that this material indicates fairly well the natural distribution of the species.

Nothing is known concerning its habits other than the situations in which they are found, which are those common to most scorpions.

\section{VAEJOVIS MEXICANUS Koch}

MEXICAN VAEJOVIS

This scorpion is dark, reddish brown and is very granular. The postabdomen is large, the vesicle rather slender and the sting short. There are no ventral keels on the first two segments of the postabdomen. Length about 4.5 to $5.5 \mathrm{~cm}$.

The species is probably the most widely distributed of any in Mexico occurring from Mexico City to the southwestern part of the United States. In the mountainous regions of Mexico it breaks up into two distinct subspecies, dugesi Pocock and smithi Pocock. In the National Museum collection there is but a single specimen which was taken at Eagle Pass, Tex. In the Baerg collection there is a specimen from Durango, Mexico, and two from Guatimape, Mexico. 


\section{VAEJOVIS SPINIGERUS (Wood)}

\section{STRIPED-TAILED SCORPION}

This species (pl. 2, fig. 4) is easily recognized from the others occurring in the region where it is found by its large size and the presence of four longitudinal dark stripes on the under side of the "tail," or postabdomen. It varies in length from about 5 to $8 \mathrm{~cm}$. and is rather stout-bodied and is exceeded in size in the Southwest only by Hadrurus hirsutus (Wood) (pl. 1, fig. 1), a hairy species of a different genus.

Its home is the desert region of the Southwest where it has been reported from Texas to California. The type specimens were taken in Texas. This species must range far into northern Mexico, but it is not represented in the Baerg collection from the State of Durango.

It is found particularly in rocky waste places where there is some moisture. However, during the spring of 1927 the writer took two adults under a large rock at a street corner in the center of the town of Tempe, Ariz. It is the most common scorpion in the Papago Saguaro National Monument, in the Salt River Valley, Ariz. At Yuma, Ariz., a persistent search for it by the writer failed in locating specimens. However, on May 4, 1927, E. E. Russell, of the Bureau of Entomology, took three specimens here along the reclamation levee and railroad track. A few years ago the writer determined a number of specimens of this species from southern New Mexico, for Dr. W. J. Baerg.

Baerg (1924) allowed this species to sting him and reported the results as follows:

"The sensation was very much like that of a pin prick, and the resulting pain, which was very slight, lasted scarcely half an hour. There was no white area around the punctures and not the slightest swelling or inflammation."

\section{VAEJOVIS FLAVUS Marx}

This yellowish species is probably our most slender representative of the genus. The pedipalps are particularly weak and slender and the hands smooth and without keels. The fourth and fifth segments of the postabdomen are scarcely as stout as those in front of them.

The species occurs in the arid Southwest, but is rarely encountered. Two specimens are in the National Museum, one from Albuquerque, N. Mex., and one from "Fort Yuma," Ariz. Records from Mexico appear to be wanting. The species doubtless occurs in that country near the United States border. 


\section{VAEJOVIS CAROLINIANUS Beauvois}

\section{SOUTHERN UNSTRIPED SCORPION}

Besides the common striped scorpion, Centruroides vittatus (Say) (pl. 2, fig. 5), there is another scorpion species somewhat smaller that is found in many of the Southern States. This species, V. carolinianus, is unmarked, of a dark reddish brown, with a large postabdomen and rather slender pedipalps. A museum specimen measures slightly over $4 \mathrm{~cm}$. in length.

The species ranges from South Carolina to Texas. In the National Museum collection there are specimens from Alabama, Georgia, and Kentucky. Little is known about the habits of this species.

\section{VAEJOVIS SUBCRISTATUS Pocock}

This Mexican scorpion is of medium size (length $5.15 \mathrm{~cm}$. male, 5.20 female, according to Pocock) and has the body mottled above with reddish yellow and blackish brown. The first two segments of the abdomen are broader than long. Pocock (1902) reports it from San Andres and Jalapa, Mexico. The only United States record that the writer has found for this species is by Borelli (1909), who reports two young females from Tucson, Ariz., taken by Professor Silvestri.

\section{VAEJOVIS SILVESTRII Borelli}

Borelli (1909) described as new a scorpion taken by Silvestri in the Sierra Madre Mountains, Southern California. This appears to be the only scorpion taken by this collector in a region rich in described species. The species can not be satisfactorily placed, and may be a synonym of one of the several species of Vaejovis known from this region.

\section{Genus ANUROCTONUS Pocock}

In Anuroctonus the middle area of the pectines is broken up, sometimes in an indistinct manner, into seven or less pieces; and these divisions are unequal. The sting is sometimes bulbous near the base. But one species of the genus is known from the United States and northern Mexico.

\section{ANUROCTONUS PHAIODACTYLUS (WoOd)}

\section{SHINY-STINGED SCORPION}

Not only has this scorpion a shiny sting, but a most peculiarly shaped one. Between the tip of the sting and the base, but nearer the latter, there is an inflated, bulbous structure. Probably the term "swollen-stinged scorpion" or "bladder-stinged scorpion" would be equally appropriate with the one given at the heading of this para- 
graph, which was originally suggested by Essig. This scorpion is from 5 to $6 \mathrm{~cm}$. long, with a reduced postabdomen but a very large vesicle. The pedipalps are stout and the fingers short and strongly curved. These are black, while the remainder of the scorpion is a reddish brown.

The shiny-stinged scorpion has a wide distribution. Pocock (1902) reports it from Virginia, Colorado, Utah, California, and Guatemala. The first of these records, however, should be questioned. The species probably does not occur in a state of nature in eastern United States. National Museum specimens are from Utah and California.

\section{Genus UROCTONUS Thorell}

Uroctonus differs from Anuroctonus in the nature of the divisions of the middle area of the pectines. This area is broken up into over five pieces, the most of which are subequal. Only a single species is reported from United States and northern Mexico.

\section{UROCTONUS MORDAX Thorell}

\section{MORDANT SCORPION}

The mordant scorpion has large pedipalps and stout hands, while the "tail" is somewhat reduced. The sting is but slightly curved, except toward its tip. It is a dark-brown species, the carapace and pedipalps being darker than the abdomen, and the abdomen in turn is darker than the legs.

$U$. mordax is a Pacific coast species, being reported from California and Oregon. Banks (1910) reports it from nine localities in California, including one record from Santa Rosa Island. Borelli (1909) reports it from Oregon. In the National Museum collection there are four lots of specimens, all from California. The habits of the species have not been studied.

\section{Family BUTHIDAE}

The family Buthidae is at once distinguished from our other American families of scorpions by the shape of the sternum. The sternum is triangular, the sides being strongly convergent anteriorly. The membrane at the base of the last tarsal segment of most of the legs has two unbranched spurs. The fixed arm of the chelicerae is without a ventral tooth.

The family Buthidae is the most widely distributed of all the families of scorpions. It is the only family to be represented in each of the six chief zoogeographical regions. Not only is it found in all these regions, but from several to many species are found in 
each of them. Kraepelin (1905) gives the number of genera and species for the zoogeographical regions as follows:

\begin{tabular}{|c|c|c|}
\hline 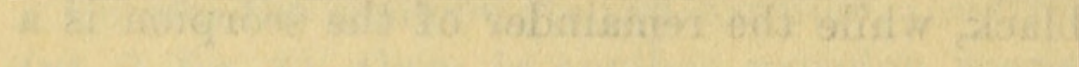 & Genera & Species \\
\hline $\begin{array}{l}\text { Ethiopian } \\
\text { Palaearctic } \\
\text { Oriental } \\
\text { Australian. } \\
\text { Nearctic } \\
\text { Neotropical. }\end{array}$ & $\begin{array}{r}11 \\
5 \\
8 \\
3 \\
2 \\
4\end{array}$ & $\begin{array}{r}95 \\
62 \\
45 \\
8 \\
22 \\
61\end{array}$ \\
\hline
\end{tabular}

Four genera are now known to occur in the United States. They are keyed out as follows:

KEY TO THE GENERA OF BUTHIDAE OCCURRING IN THE UNITED STATES

$A^{1}$. First tarsal segment of legs III and IV with a distal spur_-_Uroplectes Peters. $A^{2}$. First tarsal segment of leg IV without distal spur.

$B^{1}$. Oblique rows of teeth on fingers of chelae flanked with supernumerary rows of teeth

Centruroides Marx.

$B^{2}$. Fingers of chelae without flanking supernumerary rows of teeth.

$C^{1}$. Most of oblique rows of teeth on fingers of chelae overlapping.

$\mathrm{C}^{2}$. Rows of teeth on fingers of chelae not overlapping.

Tityus Koch.

Isometrus Hemprich and Ehrenberg.

\section{Genus UROPLECTES Peters}

Uroplectes differs from our other genera of Buthidae in having a distal spur on the first tarsal segment of legs III and IV. It is a genus that belongs to the Old World, our species apparently being an introduction.

\section{UROPLECTES MEXICANUS Comstock 2}

\section{MEXICAN UROPLECTES}

Under this name Comstock (1912) describes a species as follows: "This is a pale species. There is no spine under the sting; the teeth on the finger of the palpus are in many oblique rows, with stouter teeth at the end of each and to one side; there are from 30 to 35 teeth in the combs; and the keels on the under side of the last caudal segment are very strongly toothed."

He writes that the species has been found in Texas and California. Kraepelin (1905) is of the opinion that this scorpion probably was introduced from the Old World. Banks (1910) does not include it in his list of California scorpions. There are no specimens of American Uroplectes in the National Museum collection.

\footnotetext{
2 Comstock's 1912 description is the first for this species. He appears to have used Banks's manuscript name Uroplectes mexicanus.
} 


\section{Genus CENTRUROIDES Marx}

In Centruroides the first tarsal segment of leg IV is without a distal spur; the teeth of the fingers are arranged in oblique rows with supernumerary rows on each side. This genus is exclusively American, but in this continent has a wide range, being found from Central United States to Chile. Many species are included in it. A key is here given to those of the western part of our country.

KEX TO THE CENTRUROIDES OF WESTERN UNITED STATES

$\mathbf{A}^{\mathbf{1}}$. Length over $8 \mathrm{~cm}$; body unstriped. Large dark species.

$B^{1}$. Fingers of hand furnished with nine middle rows of teeth, exclusive of short apical row C. nigrescens Pocock.

$B^{3}$. Fingers of hand with only eight middle rows of teeth, exclusive of short apical row c. margaritatus (Gervais).

$\mathrm{A}^{2}$. Length less than $7 \mathrm{~cm}$. Reddish brown or striped species.

$\mathrm{B}^{1}$. Sting without ventral spine or tubercle near base; fingers one and a half times as long as hand_..._._._._._._._._._._. exilicaudata (Wood).

$\mathrm{B}^{2}$. Sting with a ventral spine or tubercle.

$\mathrm{C}^{1}$. Abdomen with two more or less interrupted longitudinal stripes above; sting with a spinelike tubercle below.

$D^{1}$. Black stripes irregular but never appearing as a row of dots. Eastern species. C. vittatus (Say).

$D^{2}$. Black stripes partly or entirely interrupted at each body segment so as to appear as a row of spots. Found in California

c. californicus (Girard).

$\mathrm{C}^{2}$. Abdomen without longitudinal stripes; sting with a vestigial tubercle below; dorsal surface of abaomen very rough.

C. sculpturatus, new species.

\section{CENTRUROIDES NIGRESCENS (Pocock)}

\section{BLACK SCORPION}

C. nigrescens is a large, long, black scorpion. The color varies from a very dark chestnut brown to a jet black. The appendages are slender, the fingers being about one and a half times as long as the hand. The postabdomen is much longer than the abdomen. The sting is very long and curved with a sharp subaculear tubercle. A large National Museum specimen measures $10 \mathrm{~cm}$. in length.

Pocock (1902) reports this species from Xautipa and Amula in Guerrero, Orizaba, Mexico. Borelli (1909) does not mention it in his list. Banks (1910) does not give it in his list of California scorpions. In the National Museum collection there are two specimens from Eagle Pass, Tex., and one from San Antonio, Tex. H. B. Parks, apiculturist at the state apicultural research laboratory, a few miles south of San Antonio, Tex., told the writer that he is familiar with a large, black scorpion the description of which fits this species. While collecting scorpions at San Antonio the writer did not see any examples of the species. 


\section{CENTRUROIDES MARGARITATUS (Gervais)}

$C$. margaritatus is similar in general appearances to $C$. nigrescens, but has one less row of teeth in the middle series on the fingers, and the basal segments of the postabdomen and the legs are lighter in color than the body. Male specimens measure as much as $10 \mathrm{~cm}$. in length.

This is a widely distributed species occurring in America from the southern United States to Brazil and Chile and, according to Pocock, is found in West Africa. Comstock (1912) reports it from Florida. Pocock (1902) states that there are specimens in the British Museum from California. Banks (1910) does not include it in his list of California scorpions. Specimens from the United States are wanting in the National Museum. According to Baerg (1925) this species is the one most commonly met in the Panama Canal Zone.

Baerg (1925) experimented with this species, inducing it to sting white mice and himself. The effect on the mice was not serious, and the bitten area showed no inflammation or other effect. When the scorpion stung Doctor Baerg there was a severe pain at first and the affected area was reddish. No permanent effects were produced. Baerg reports the experiences of two scientists who were stung by this species. In these cases there was considerable swelling produced and in one case some lameness in the tongue.

\section{CENTRUROIDES EXILICAUDATA (Wood)}

\section{SLENDER-TAILED CENTRUROIDES}

This scorpion not only has a slender tail, or postabdomen, but also slender appendages. The fingers of the hand are very slender, being about one and a half times as long as the hand proper. In the male the postabdomen is almost twice as long as the abdomen. There is no vestige of a tooth or tubercle under the sting. The absence of this tooth alone distinguishes this species from all other United States species of its genus. A male specimen in the National Museum collection measures $5.1 \mathrm{~cm}$. in length.

This species was orginally described from Lower California, the type specimens being in the National Museum. Also in the National Museum there are a number of specimens from Lower California, most of them coming from Cape San Lucas, but there are two specimens coming from San Diego, Calif.

According to Jackson (1910) the stings of this species may prove fatal to man. In fact he attributes many deaths to it in the State of Durango, Mexico. It is possible in this connection, however, that the species involved was not $C$. exilicaudata, as I do not find it in a large collection of scorpions taken in Durango by Baerg. 
This species (pl. 2, fig. 5) which is frequently referred to as $C$. carolinianus (Wood), has two broad, dark longitudinal bands on the dorsal side of the abdomen. In young specimens these bands are usually entire, but in most of the mature individuals they are partly or even entirely interrupted at the middle of each abdominal tergite. In adults of both sexes the appendages and the postabdomen are of a uniform yellowish brown except for the distal part of the sting, which is black. In young specimens the hands and the fifth segment of postabdomen are black, and the postabdomen has three longitudinal black stripes below. Male specimens have a very long postabdomen, but that of the female is only about a third longer than the abdomen. A male specimen measures $6.7 \mathrm{~cm}$. in length, a female specimen, $5.9 \mathrm{~cm}$.

C. vittatus probably occupies a greater area of the United States than any other scorpion. Pocock (1902) reports it from Georgia, Florida, Kansas, Texas, and California. The California record, however, should be ascribed to another species. Specimens in the National Museum are from Arkansas, Louisiana, New Mexico, and Texas. The species has also been reported from South Carolina and doubtless occurs in all the Gulf States as well as Kentucky, Tennessee, and Missouri.

Concerning the habits and life history of this species considerable is known. Out of doors it is found very abundantly under the loose bark of large trees and logs, and under logs and stones on the ground. About human habitations it prefers probably above all else the woodpile and crumbling stone or brick foundations. In some parts of Texas the writer has found it infesting back yards, and reports of its infestation of houses have been frequent. A number of specimens have been kept in captivity by the writer. One adult received October 2, 1925, was kept alive until late in August of 1926. In captivity $C$. vittatus feeds readily upon small roaches and flies, but refuses many kinds of insects and nearly all of the larger or hard ones. While other scorpions have been observed to dig into the ground in captivity, such a habit was not observed in this species. $C$. vittatus has a habit of clinging to objects lying on the ground, so that when the latter are turned over with the hands one is liable to press upon the scorpion and get stung.

The life history of $C$. vittatus has been studied by Smith (1927). He found the species to be ovoviviparous. Each young "was born in a very thin and transparent envelope from which it freed itself in about 15 minutes." The young molted in from 3 to 6 days 
and remained on the back of the mother from 5 to 15 days. Smith estimates the period of growth at from three to four years.

The writer has induced this species to sting him and has observed the effects of its sting on others. At the time of the stinging there is a sharp pain, but this soon subsides. A small swollen area, or wheal, usually develops about the puncture point. This soon disappears. There are no permanent effects of the sting reported for the species as far as known to the writer.

\section{CENTRUROIDES CALIFORNICUS (Girard)}

CALIFORNIA CENTRUROIDES

The striped scorpion of California has been considered as a synonym of $C$. vittatus by Pocock (1902), but as pointed out by Wood it differs from vittatus in a number of ways. In the National Museum there are three specimens from California determined by Marx. Two of these are from Lake County and are labeled " $C$ entrumus vittatus Say var. californicus W." and one is from Tule Lake and is labeled "vittatus Say" without any variety being given.

An examination of these specimens shows that the Lake County specimens are similar to vittatus but lack any definite dorsal stripes and have the integument much more roughened and in a manner noted by Wood. The one specimen from Tule Lake is without the subaculear tooth or practically so. It should be referred either to C. exilicaudata or a new species now to be described. All dorsal colorations are wanting in this specimen, but this condition may be due to the preservative used.

\section{CENTRUROIDES SCULPTURATUS, new species}

The writer has found an unstriped rough species (pl. 2, fig. 6) with a subaculear tooth in southern Arizona. It is related to exilicaudata but has the subaculear tooth. It is also related to vittatus and californicus but has neither spots or bands dorsally. It is described as follows:

General color a yellowish brown. There are no dorsal stripes, spots, or other color markings. Cephalothorax without dorsal color markings; median groove pronounced; integument granular. Hands slender, fingers about one and a half times as long as hand. On the posterior part of the carapace there is a pair of longitudinal, tuberculate, carinae that extend forward from the posterior margin about one-half the distance to the eyes. They are situated about one-third the distance from the median groove to the lateral margin of the carapace. Abdomen very coarsely granular above; each tergite with a more or less distinctly elevated tuberculate posterior margin and a well-developed median carina. Postabdomen longer than abdomen; 
first segment about twice as long as broad; last segment with a long, slender, strongly curved sting, a low pointed tubercle below the sting and a swollen vesicle. About 24 teeth in pectinal comb. Length,

$5.2 \mathrm{~cm}$.

Type locality.-Tempe, Ariz.

Type-Cat. No. 973, U.S.N.M.

Description based upon two adult specimens, a part of two lots as follows: One adult and one young from Tempe, Ariz., March 29, 1927 , by the writer, under a stone in a rocky place, and one adult and one young from the same place, April 1, 1927, by the writer, under stones near a camp of Mexicans.

\section{CENTRUROIDES OF NORTHERN MEXICO}

In addition to the Centruroides species reported from the western United States in this paper, all of which probably occur in northern Mexico, there are others found there, which as far as known do not extend as far north as the United States boundary. These will be mentioned.

\section{CENTRUROIDES SUFFUSUS Pocock}

Judging from the material collected by Doctor Baerg in Mexico this is the common scorpion in the State of Durango. It is the Sonoran representative of vittatus, from which it differs in having the dorsal black stripes wider than the median yellow one and in having the interocular triangle but slightly, if at all, darker than the area behind the ocular tubercle, as well as in a few other particulars. It is near exilicaudata, but has bright stripes on the abdomen and a minute tubercle under the sting.

Pocock described suffusus as a subspecies of vittatus. This material came exclusively from the State of Durango, Mexico. Although compared with Centruroides elegans in the original description, the closest affinity of this form is probably with $C$. ornatus Pocock, of which it might with some propriety be considered a variety.

\section{CENTRUROIDES ORNATUS Pocock}

ORNATE SCORPION

Pocock described this species from Jalisco, Mexico. It is almost indistinguishable from his suffusus. In fact, the writer is somewhat inclined to consider the common striped scorpion of Durango, if it were to be recognized as only a subspecies, as a subspecies of ornatus rather than vittatus as was done by Pocock. Further collecting in Central Mexico will throw much light upon the true affinity of ornatus. One specimen in the Baerg collection from Atotonilco, Mexico, should be referred to this species. 
CENTRUROIDES CHIARAVIGLI Borelli

Borelli (1915) described as new a species taken at Dinamita, State of Durango, Mexico. According to his description it is a pale yellowish species, with a triangular brown spot on the anterior part of the cephalothorax. The cephalothorax is densely and finely granular. The teeth in the pectinal comb of the male are 28 to 29 ; in that of female, 26 to 27 . Length of male is given as $7 \mathrm{~cm}$; of female, 5.3 $\mathrm{cm}$. Numerous examples of males, females, and young were obtained.

Borelli's description of this species is very suggestive of $C$. suffusus Pocock. That the males should exceed the females by $1.7 \mathrm{~cm}$. in length is somewhat unusual. Pocock gives lengths of suffusus as follows: Male, $6.2 \mathrm{~cm}$.; female, $4.6 \mathrm{~cm}$. The ratio of Pocock's measurements are, however, similar to those of Borelli. I can find nothing in Baerg's collection of scorpions to correlate with this species except suffusus, which agrees in many respects.

\section{Genus TITYUS Koch}

In Tityus the first tarsal segment of leg IV is without distal spur. The fingers are provided with overlapping oblique rows of teeth but there are no supernumerary flanking rows.

This is an American genus. It is best represented in the Tropics but extends from California and Florida to Argentina. Only two United States species are known. They may be separated as follows:

KEY TO UNITED STATES SPECIES OF TITYUS

$A^{1}$. Sting with large ventral tooth near base; total length about $8 \mathrm{~cm}$. Found in Florida

T. floridanus Banks.

$A^{2}$. Sting without a ventral tooth; total length about $5 \mathrm{~cm}$. Found in California

T. tenuimanus Banks.

\section{TITYUS TENUIMANUS Banks}

CALIFORNIA TITYUS

Our knowledge of this species is limited to the original description of it which was published in 1910. It is described as a yellowishbrown scorpion, 2 inches in length, with a weakly keeled hand and long fingers. It differs markedly from the Florida speciés, in the absence of the tooth below the sting and in its much smaller size. The only record for it is from Buena Vista Lake, Calif.

\section{Genus ISOMETRUS Hemprich and Ehrenberg}

Isometrus is similar to Tityus, but the rows of teeth on the fingers of the chelae do not overlap. There are no supernumerary rows of flanking teeth.

The genus is represented in both the Old and New Worlds. 


\section{ISOMETRUS EUROPAEUS LInnaeUs}

This long known and widely distributed species is remarkable for the degree of sexual dimorphism shown. The female is of a rather slender body, but in the male the postabdomen and appendages are exceedingly slender. The postabdomen of the male is about twice as long as the body and the hand is about four times as long as broad. The general color is a reddish brown. The subaculear tooth is long, sharp, and conspicuous. The length of the male is from 6 to $7 \mathrm{~cm}$. The species is frequently known under the name of $I$. maculatus De Geer.

This scorpion is reported from many parts of the world. It occurs in South America and the West Indies. In the United States it is known from Florida and California. There are two specimens in the National Museum, both from Key West, Fla.

BAERG, W. J.

\section{LITERATURE CITED}

1924. The Effect of the Venom of Some Supposedly Poisonous Arthropods. An. Ent. Soc. Amer., vol. 17, pp. 343-352, 7 figs.

1925. The Effect of the Venom of Some Supposedly Poisonous Arthropods of the Canal Zone. An. Ent. Soc. Amer., vol. 18, pp. 471-478.

BANKS, N.

1910. The Scorpions of California. Pomona College Journ. Ent., vol. 2, BorRelli, A. pp. 185-190, figs. 80-81.

1909. Scorpioni raccolti dal Prof. F. Silvestri nell' America settentrionale e alle isole Hawaii. Bol. Lab. Zool. Port., vol. 3, pp. 222-227.

1915. Scorpioni nuovi o poco noti del Messico. Bol. Mus. Zool. and Anat. Comp. Torino, vol. 30 , pp. 1-7.

Chamberlin, R. V.

1924. The Northern Range of the Scorpion. Science, vol. 59, p. 64. Coмsтоск, J. H.

1912. The Spider Book, 721 pp., 770 figs. Doubleday, Page and Co. de Mello Campos, O.

1924. Os escorpiones brazileiros. Mem. Inst. Oswaldo Cruz, vol. 17, fasc. Fssig, E. O.

$$
2 \text {, pp. 237-363, pls. 2-13. }
$$

1926. Insects of Western North America, 1035 pp., 766 figs. Macmillan Co.

JACKsoN, H. V.

1910. Interstate Medical Journal, vol. 17, No. 7.

KrAEPELIN, K.

1905. Die geographische Verbreitung der Scorpione. Zool. Jahrb. Jena, vol. 22 , pp. 321-364.

1911. Neue Beiträge zur Systematik der Gliederspinnen. Jahrb. Hamb. wissensch. Amst., 2 Beih, vol. 28, pp. 60-108, 9 figs., 1 pl.

Pocock, R. I.

1902. Arachnida-Scorpiones, Pedipalpi and Solifugae. Biol. Cent.-Amer.,

Sмiтh, F. R.

71 pp., 12 pls.

1927. Observations on Scorpions. Science, vol. 65, p. 64 .

WEBSTER, R. L.

1923. Scorpion in North Dakota. Science, vol. 58, p. 248. 


\section{EXPLANATION ON PLATES}

All photographs were taken by J. G. Pratt and are natural size.

\section{Plate 1}

Fic. 1. Hadrurus hirsutus (Wood). Specimen from Calexico, Calif.

2. Vaejovis boreus (Girard). Specimen from Fort Pierre, S. Dak.

\section{Plate 2}

Fig. 3. Vaejovis yosemitensis, new species.

4. Vaejovis spinigerus (Wood). Specimen from Papago Saguaro National Monument, Ariz.

5. Centruroides vittatus (Say). Male specimen from Texas.

6. Centruroides sculpturatus, new species. Specimen from Temple, Ariz.

O 


\section{$2 \mathrm{BHL}$ Biodiversity Heritage Library}

Ewing, H. E. 1928. "The scorpions of the western part of the United States, with notes on those occurring in northern Mexico." Proceedings of the United States National Museum 73(2730), 1-24. https://doi.org/10.5479/si.00963801.73-2730.1.

View This Item Online: https://www.biodiversitylibrary.org/item/53485

DOI: https://doi.org/10.5479/si.00963801.73-2730.1

Permalink: https://www.biodiversitylibrary.org/partpdf/52410

\section{Holding Institution}

Smithsonian Libraries

\section{Sponsored by}

Smithsonian

\section{Copyright \& Reuse}

Copyright Status: Public domain. The BHL considers that this work is no longer under copyright protection.

This document was created from content at the Biodiversity Heritage Library, the world's largest open access digital library for biodiversity literature and archives. Visit BHL at https://www.biodiversitylibrary.org. 